\title{
Time dependent of epigenetic effect of disulfiram on tumor suppressor gene of RASSF1A in Hela cancer cell line
}

Seyedeh Naghme Noorirad ${ }^{1}$, Mohsen Pourghasem ${ }^{1}$, Farideh Feizi $^{1}$, Zeinab Abedian $^{2}$, Masoumeh Ghasemi ${ }^{2}$, Zahra Babazadeh ${ }^{*}$, Navid Rabiee ${ }^{3}$

1. Department of Anatomical Sciences, Faculty of Medicine, Babol University of Medical Sciences, Babol, Iran

2. Cellular and Molecular Biology Research Center, Health Research Institute, Babol University of Medical Sciences, Babol, Iran

3. Department of Chemistry, Shahid Beheshti University, Tehran, Iran

*Corresponding author:Tel: +98 9113548969 Fax: +98 -

Address: Department of Anatomical Sciences, Faculty of Medicine, Babol University of Medical Sciences, Babol, Iran

E-mail:zbabazadeh@gmail.com

Received; 2017/06/1 revised; 2017/07/4 accepted; 2017/08/4

\section{Abstract}

Introduction: Cervical cancer is the third most common tumor among women. Surgery, radiotherapy, and chemotherapy are common treatments, however high stage tumors have frequently poor prognosis. Nowadays, the epigenetic reversion introduced as an efficient strategy of treatment of cervical cancer. In the process, inhibitors of DNA methyltransferase (DNMT) induce re-expression of tumor suppressor genes. Among these inhibitors, disulfiram (DSF) has been suggested as non-nucleoside analogous. In this research, we evaluated the epigenetic effect of DSF on demethylation of the tumor suppressor gene, RASSF1A, in Hela cell line.

Materials and methods: Hela cells were cultured and treated with different doses from 2.5 to $37.5 \mu \mathrm{M}$ during 24,48 and 72 hours. MTT assay was carried out to find half maximal inhibitory concentration $\left(\mathrm{IC}_{50}\right)$. The methylation specific PCR (MSP) assay was applied to evaluate methylation pattern.

Results: The $\mathrm{IC}_{50}$ of DSF was determined at the $2.5,12.5$, and $15 \mu \mathrm{M}$ after 72 hours. The MSP results showed partial demethylation at mentioned concentrations after $72 \mathrm{~h}$ but unmethylated band was not observed after $24 \mathrm{~h}$.

Conclusion: Our findings indicated that, $\mathrm{IC}_{50}$ of DSF exerted a biphasic effect in Hela cell line and at least 72 hours treatment is needed for the epigenetic reversion of DSF on RASSF1Ain Hela cell line.

Keywords: Disulfiram, RASSF1A, Epigenetic reversion, Methylation, Cervical cancer

\section{Introduction}

Cervical cancer is the third most common cancer among women; around $70 \%$ of the patients are infected by HPV (16/18) virus(1-2). Unfortunately, this neoplasia is one of the most common life-threatening diseases in the world and the patients usually have less than 5 years survival time after diagnosis. Although combined treatment of chemotherapy, surgery and radiotherapy are recommended for this cancer, still it has poor prognosis(3-4).

Copyright (C) 2018 Journal of Basic Research in Medical Science. This is an open access article distributed under the terms of the Creative Commons Attribution 4.0 International License (https://creativecommons.org/licenses/by/4.0/) which permits copy and redistribute the material, in any medium or format, provided the original work is properly cited. 
Recent studies have demonstrated the role of epigenetic and genetic factors in tumorogenesis. Epigenetic events show phenotype alterations without genetic alterations(5). DNA hypermethylation and histone modification are two important epigenetic events (6). DNA hypermethylation in CPG Islands of promoter region in tumor suppressor genes induces gene silencing without alteration in DNA sequences which are inherited from one generation to the next (7-8).

RASSF1A is one of the critical tumor suppressor genes that induce apoptotic signaling, microtubule stability and cell cycle arrest (9). In one hand, the inactivation of tumor suppressor genes usually occurs by mutation in one allele and hypermethylation in the others. RASSF1A inactivation was reported in different kind of cancers such as lung, breast, bladder, prostate, kidney and cervix (10). On the other hand, RASSF1A is routinely expressed in normal tissue and regulates normal cell cycle, apoptosis, DNA repair and inhibits tumorigenesis (9). Fortunately, the epigenetic events are reversible, for instance using DNA methyl-transferase inhibitor (DNMTi) drugs are recommended to revise abnormal methylation in promoter region of tumor suppressor genes(11). The DNMTs inhibitor drugs are characterized in two groups, which called the cytosine analogous and non-cytosine analogous(12). The cytosine analogous DNMTi such as 5Aza-CdR which was approved by FDA and used as combined cancer therapy in lymphoma and hematopoietic cancer is toxic (13). As a result, cytosine-like structure in this group can replace cytosine during DNA duplication that induces mutation. Thus,taking steps to find a new approach of cancer therapy of nonnucleoside analogous of DNMT inhibitors seems to be obligatory (14).

For more than 50 years, DSF has been advised for alcohol abuse, but, recent studies have demonstrated the antineoplastic effect of this drug on different tumors and cancer cell lines such as
Melanoma, glioma, lung carcinoma, and leukemia(15). Because of strong reactive functional thiol groups in chemical structure of DSF, DSF is suggested as a non-nucleoside analogous of DNMT inhibitors that can be able to attack the cytosine sites on DNA to remove methylated group (16). The exact antineoplastic effect of DSF is not clear, so in this study we investigated the epigenetic effect of DSF on re-expression of RASFF1A on cervical cancer cell line.

\section{Material and methods}

Cell line and cell culture: Hela was prepared from the cellular and molecular lab of Babol University of Medical Sciences, and MRC-5 was obtained from National Cell Bank of Pasteur Institute of Iran. Cells were cultured in RPMI (Biowest, France), 10\% FBS, 1\% penicillin streptomycin (Sigma, USA) at $37^{\circ} \mathrm{C}$ and $5 \%$ $\mathrm{CO}_{2}$. When they reach $80 \%$ confluence, $2 \times 10^{4}$ cells were transferred to 24 well cell cultures.

DSF treatment: The stock solution of DSF $(50 \mathrm{mM})$ was dissolved in DMSO (Sigma, USA) and stored at $20^{\circ} \mathrm{C}$. Serial dilutions were prepared in different concentrations based on drug reference. Cells were treated with $0,2.5,5,7.5,10,12.5,15,17.5,20$, $22.5,25,27.5,30,32.5,35 \mu \mathrm{M}$ one day after seeding for 24,48 and $72 \mathrm{~h}$. The $\mathrm{IC}_{50}$ of DSF was obtained at $2.5,12.5,15 \mu \mathrm{M}$ for $72 \mathrm{~h}$.

MTT assay: The cytotoxicity of DSF was determined in Hela cell line using MTT assay. $2 \times 10^{4}$ cells were cultured in each well of a 24 well plate overnight, after that and treatment, the MTT assay was preformed as described previously (17).

DNA extraction, bisulfate treatment, and methylation specific PCR: Genomic DNAs were extracted from treated and control groups of Hela and MRC-5 cells (as unmethylated control) using Prime Prep TM Genomic DNA Isolation Kit (Genet bio, Korea) according to manufacturer's instructions. The amount of DNA extraction was measured by nano drop. The 
bisulfate modification of genomic DNA was performed on $2-\mu 1$ of genomic DNA using Epitect Bisulfite kit (Qiagen, Germany) according to the protocol. The PCR reaction was performed in thermal cycler (Thermocycler, Germany) for methylated primers as: $95^{\circ} \mathrm{C}$ for $5 \mathrm{~min}$ followed by 35 cycles of $94^{\circ} \mathrm{C}$ for $30 \mathrm{~s}, 60^{\circ} \mathrm{C}$ for $30 \mathrm{~s}$, and $72^{\circ} \mathrm{C}$ for $30 \mathrm{~s}$ and final extension $72^{\circ} \mathrm{C}$ for $4 \mathrm{~min}$.

For unmethylated primers the cycling program was as: $95^{\circ} \mathrm{C}$ for $5 \mathrm{~min}$ followed by 35 cycles of $94^{\circ} \mathrm{C}$ for $30 \mathrm{~s}, 55.3^{\circ} \mathrm{C}$ for $30 \mathrm{~s}, 72^{\circ} \mathrm{C}$ for $30 \mathrm{~s}$, the final extension $72^{\circ} \mathrm{C}$ for $4 \mathrm{~min}$. The PCR products were transferred to electrophoresis on $2 \%$ agarose gel and visualized with ethidium bromide (17).

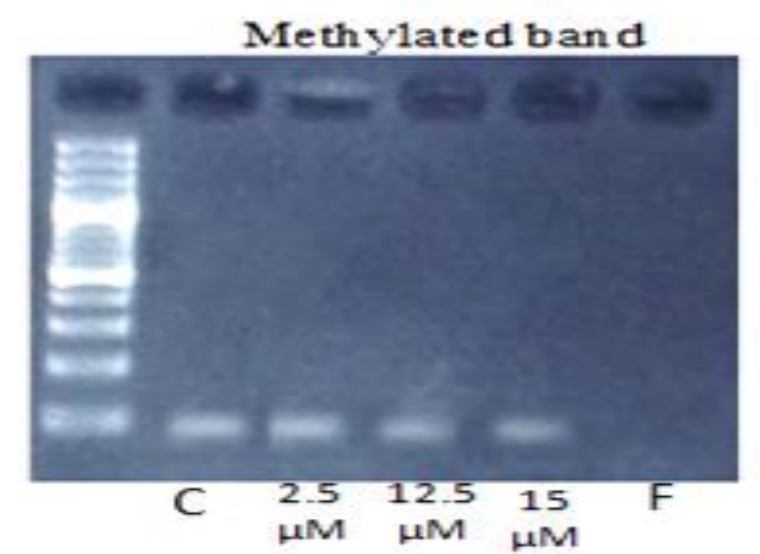

Figure 1. MSP assay was carried out to determine promoter RASSF1A methylation and unmethylation in Hela cancer cell line after DSF treatment for $24 \mathrm{~h}$. There was not observed any unmethylated band after treatment. (C: control, 2.5, 12.5, 15 $\mu \mathrm{M}$ DSF treatment, F: fibroblast)

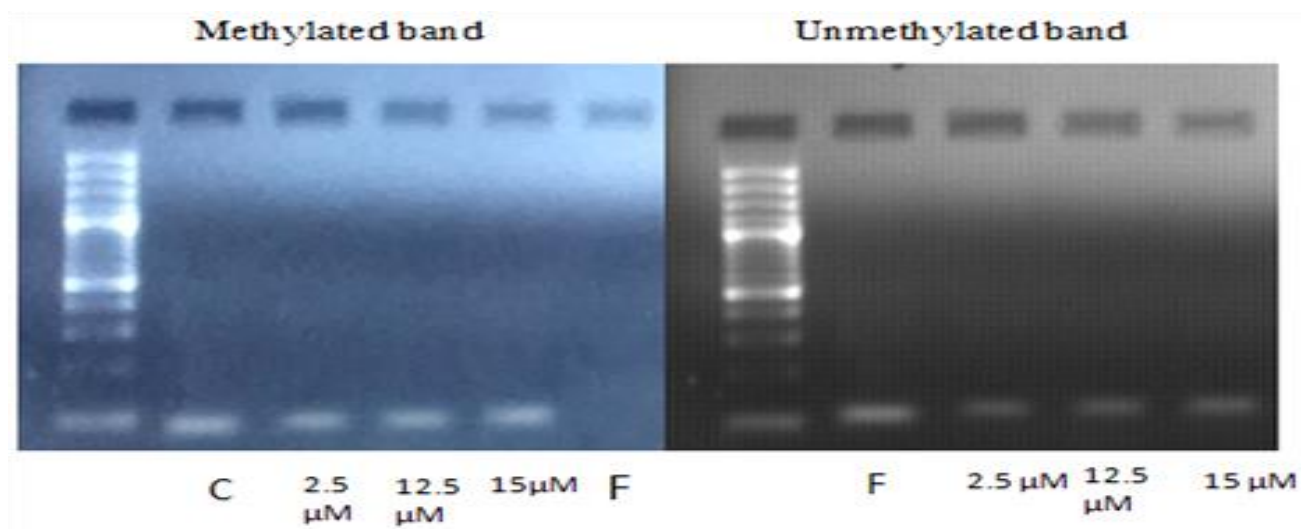

Figure 2. MSP assay was carried out to determine promoter RASSF1A methylation and unmethylation in Hela cancer cell line after DSF treatment for $72 \mathrm{~h}$. Both unmethylated and methylated bands were obtained after treatment with $2.5,12.5$ and $15 \mu \mathrm{M}$ concentrations.

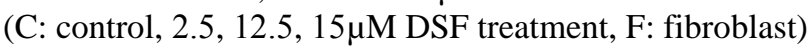




\section{Discussion}

DNA methylation is one of the significant epigenetic events in tumorogenesis(16). The important reason of alteration in DNA methylation pattern is the increase of DNMT enzyme activity in malignant tumors (5). The methylation of CpGs island promoter region of RASSF1A tumor suppressor genes are reported in different type of cancers and cancer cell lines (18). Recent studies have demonstrated DNMTs inhibitors as a new strategy in cancer therapy as combined treatment (19).

In this study, we evaluated the apoptotic effect of DSF in Hela cancer cell line. The result showed no apoptotic effect of DSF in Hela cell line after $24 \mathrm{~h}$ of treatment. Moreover, the $48 \mathrm{~h}$ treatment of DSF in Hela cell line declared no significant decrease of cell viability as well. Nevertheless, the $\mathrm{IC}_{50}$ of DSF was obtained after $72 \mathrm{~h}$ treatment. The $\mathrm{IC}_{50}$ indicated biphasic effect at 2.5, 5, $12.5 \mu \mathrm{M}$ concentrations in Hela cell line.

Our results were in accordance with the studies of Wiggins, Zhang, and Jones that demonstrated the biphasic effect of DSF inMCF-7, HePG2, and ovarian cancer cell line(OVCAR-3) (20-22), while Wickstorms and Nikbakht stated the monophasic effect of DSF in $\mathrm{ACH}$, H69AR, PRE and PANC-1, respectively(17, 23). This controversy can be explained by different responses of various cancer cell lines and tumor cells during the exposure of DSF. Furthermore, we investigated the epigenetic effect of DSF on demethylation of RASSF1Ain Hela cancer cell line. The result exhibited no epigenetic effect and no demethylation of promoter RASSF1A after $24 \mathrm{~h}$ treatment while partial demethylation was observed through $72 \mathrm{~h}$ treatment. Our results are similar with the study of Sherma that explained DSF as DNMTs inhibitors,

\section{References}

1. Torre LA, Bray F, Siegel RL, Ferlay J, Lortet- Tieulent J, Jemal A. Global induced demethylation and re-expressed ER-B in prostate cancer cell line (24). On the other hand, our results are in contrast with Nikbakht that demonstrated no epigenetic effect but apoptotic effect of DSF on PANC-1(17). This controversy can be explained as time dependent epigenetic reversion of disulfiram, to be exact $24 \mathrm{~h}$ is not a sufficient time for epigenetic reversion. Stresemann stated at least $72 \mathrm{~h}$ treatment is essential for epigenetic reversion which was in accordance with our results (25). However, Christoforou explained the decrease of DNMT enzyme activity on DU145 and prostate cancer cell line(PC-3)after 48h treatment with $\operatorname{DSF}(26)$. This controversy can be related to different doses, time dependent and different response mechanisms of tumor cells against DSF exposure.

\section{Conclusion}

DSF showed partial demethylation after $72 \mathrm{~h}$ treatment while no epigenetic reversion was found after $24 \mathrm{~h}$. In conclusion, we can found that DSF has time dependent epigenetic effect on $\mathrm{CpG}$ island promoter region of RASSF1A. As DSF is asafe drug and induces tumor specific toxicity, it is worth using it as acombined cancer therapy drug with chemotherapy and radiotherapy. In summary, our results showed the time dependent epigenetic effect of DSF in Hela cell line. After $72 \mathrm{~h}$ treatment, partial demethylation occurred in 2.5, 12.5 and 15 $\mu \mathrm{M}$ concentrations.

\section{Acknowledgments}

The authors thank Dr. EbrahimZabihi and the Cellular and Molecular Biology Research Center personnel ofBabol University of Medical Sciences for their utmost help in this study. cancer statistics 2012. CA Cancer J Clin. 2015;65(2):87-108. 
2. Chen $\mathrm{W}$, Zheng R, Baade PD, Zhang S, Zeng $\mathrm{H}$, Bray $\mathrm{F}$ et al. Cancer statistics in China 2015. CA Cancer J Clin. 2016;66(2):115-32.

3. Siegel RL, Miller KD, Jemal A. Cancer statistics 2016. CA Cancer J Clin. 2016;66(1):7-30.

4. Ujihira T, Ota T, Kusunoki S, Sugimori Y, Kimura M, Kaneda $\mathrm{H}$ et al. Outcome of neoadjuvant intra-arterial chemotherapy and radical hysterectomy for treatment of bulky stage IB to stage IIB uterine cervical cancer: can postoperative irradiation be avoided? Int J Gynecol Cancer. 2016;26(7):125863.

5. Baylin SB, Jones PA. Epigenetic determinants of cancer. Cold Spring Harb Perspect Biol. 2016;8(9):a019505.

6. Nickel A, Stadler SC. Role of epigenetic mechanisms in epithelial-tomesenchymal transition of breast cancer cells. Transl Res. 2015;165(1):126-42.

7. Okugawa Y, Grady WM, Goel A. Epigenetic alterations in colorectal cancer: emerging biomarkers. Gastroenterology. 2015;149(5):120425.

8. Mehdipour P, Santoro F, Minucci S. Epigenetic alterations in acute myeloid leukemias. FEBS J. 2015;282(9):1786800.

9. Donninger $\mathrm{H}$, Clark J, Rinaldo F, Nelson N, Barnoud T, Schmidt ML et al. The RASSF1A tumor suppressor regulates XPA-mediated DNA repair. Mol Cell Biol. 2015;35(1):277-87.

10. Li H-P, Huang H-Y, Lai Y-R, Huang J$\mathrm{X}$, Chang K-P, Hsueh $\mathrm{C}$ et al. Silencing of miRNA-148a by hypermethylation activates the integrin-mediated signaling pathway in nasopharyngeal carcinoma.

Oncotarget. 2014;5(17):7610.

11. Gnyszka A, Jastrzebski Z, Flis S. DNA methyltransferase inhibitors and their emerging role in epigenetic therapy of cancer. Anticancer Res. 2013;33(8):2989-96.

12. Singh V, Sharma P, Capalash N. DNA methyltransferase-1 inhibitors as epigenetic therapy for cancer. Curr Cancer Drug Targets. 2013;13(4):37999.

13. Deb G, Thakur VS, Limaye AM, Gupta S. Epigenetic induction of tissue inhibitor of matrix metalloproteinase3 by green tea polyphenols in breast cancer cells. Mol Carcinog. 2015;54(6):485-99.

14. Graça I, J Sousa E, Baptista T, Almeida M, Ramalho-Carvalho J, Palmeira $\mathrm{C}$ et al. Anti-tumoral effect of the nonnucleoside DNMT inhibitor RG108 in human prostate cancer cells. Curr Pharm Des. 2014;20(11):1803-11.

15. Jiao Y, Hannafon B, Ding W-Q. Disulfiram's Anticancer Activity: Evidence And Mechanisms. A Anticancer Agents Med Chem. 2016;16(11):1378-84.

16. Lin J, Haffner MC, Zhang Y, Lee BH, Brennen WN, Britton J et al. Disulfiram is a DNA demethylating agent and inhibits prostate cancer cell growth. Prostate. 2011;71(4):333-43.

17. Dastjerdi MN, Babazadeh Z, Rabbani M, Gharagozloo M, Esmaeili A, Narimani M. Effects of disulfiram on apoptosis in PANC-1 human pancreatic cancer cell line. Res Pharm Sci. 2014;9(4):287-94.

18. Grawenda A, O'neill E. Clinical utility of RASSF1A methylation in human malignancies. $\mathrm{Br} \mathrm{J}$ Cancer. 2015;113(3):372-81.

19. Joo MK, Kim KH, Park JJ, Yoo HS, Choe J, Kim HJ et al. $\mathrm{CpG}$ island promoter hypermethylation of Ras association domain family $1 \mathrm{~A}$ gene contributes to gastric carcinogenesis. Mol Med Rep. 2015;11(4):3039-46.

20. Wiggins HL, Wymant JM, Solfa F, Hiscox SE, Taylor KM, Westwell AD et al. Disulfiram-induced cytotoxicity and endo-lysosomal sequestration of 
zinc in breast cancer cells. Biochem Pharmacol. 2015;93(3):332-42.

21. Zhang L, Tian B, Li Y, Lei T, Meng J, Yang $\mathrm{L}$ et al. A copper-mediated disulfiram-loaded pH-triggered PEGshedding TAT peptide-modified lipid nanocapsules for use in tumor therapy. ACS Appl Mater Interfaces. 2015;7(45):25147-61.

22. Jones SK, Lizzio V, Merkel OM. Folate receptor targeted delivery of siRNA and paclitaxel to ovarian cancer cells via folate conjugated triblock copolymer to overcome TLR4 driven chemotherapy resistance. Biomacromolecules. 2015;17(1):76-87.

23. Wickström M, Danielsson K, Rickardson L, Gullbo J, Nygren P, Isaksson A et al. Pharmacological profiling of disulfiram using human tumor cell lines and human tumor cells from patients. Biochem Pharmacol. 2007;73(1):25-33.

24. Sharma V, Verma V, Lal N, Yadav SK, Sarkar S, Mandalapu D et al. Disulfiram and its novel derivative sensitize prostate cancer cells to the growth regulatory mechanisms of the cell by re- expressing the epigenetically repressed tumor suppressor-estrogen receptor $\quad \beta$. Mol Carcinog. 2016;55(11):1843-57.

25. Stresemann C, Brueckner B, Musch T, Stopper H, Lyko F. Functional diversity of DNA methyltransferase inhibitors in human cancer cell lines. Cancer Res. 2006;66(5):2794-800.

26. Christoforou P, Christopoulos PF, Koutsilieris $M$. The role of estrogen receptor $\beta$ in prostate cancer. Mol Med. 2014;20(1): 427-34. 